\title{
Chimeric Mice Carrying 'Regional' Targeted Deletion of the Angiotensin Type 1A Receptor Gene

\author{
Evidence against the Role for Local Angiotensin in the In Vivo Feedback Regulation of Renin Synthesis in \\ Juxtaglomerular Cells
}

\author{
Taiji Matsusaka, ${ }^{*}$ Hideki Nishimura, ${ }^{*}$ Hirotoshi Utsunomiya, ${ }^{\ddagger}$ Junji Kakuchi, ${ }^{*}$ Fumio Niimura, ${ }^{\star}$ Tadashi Inagami, ${ }^{\ddagger}$ \\ Agnes Fogo, ${ }^{\S}$ and lekuni Ichikawa* \\ $*$ Department of Pediatrics, ${ }^{\ddagger}$ Department of Biochemistry, and ${ }^{\S}$ Department of Pathology, Vanderbilt University School of Medicine, \\ Nashville, Tennessee 37232
}

\begin{abstract}
We have developed chimeric mice carrying 'regional' null mutation of the angiotensin type 1A (AT1A) receptor, the AT1 receptor subtype exclusively present in mouse juxtaglomerular (JG) cells. The chimeric mouse (Agtr1a $-I-\leftrightarrow$ $+I+)$ is made up of wild-type (Agtrla $+I+)$ cells or cells homozygous for Agtrla deletion (Agtrla -/-). In the latter, the AT1A coding exon was replaced with a reporter gene, lacZ. In Agtrla $-I-\leftrightarrow+/+$ mice, these two clones of cells are found to be clustered and display patchy distributions in the kidney and heart. Tracking of lacZ activities in hetero(Agtr1a $+I-)$ and homozygous (Agtrla $-I-)$ deletion mutant offspring from Agtrla $-I-\leftrightarrow+I+$ mice revealed that the promoter activity of Agtr1a is localized in JG cells, afferent arteriolar walls, glomerular mesangial region and endothelial cells, and apical and basolateral proximal tubule membranes. The JG apparatuses of Agtrla -I- mice are markedly enlarged with intense expression of renin mRNA and protein. In Agtr1a $-I-\leftrightarrow+I+$ mice, these changes were proportional to the degree of chimerism. Within a given Agtrla $-I-\leftrightarrow+I+$ mouse, however, the degree of JG hypertrophy/hyperplasia and the expression of renin mRNA and protein were identical between Agtrla $+/+$ and Agtrla -I- cells. Thus, in the in vivo condition tested, the local interaction between angiotensin and the AT1 receptor on the JG cells has little functional contribution to the feedback regulation of JG renin synthesis. (J. Clin. Invest. 1996. 98:1867-1877.) Key words: kidney • heart • afferent arteriole - efferent arteriole $\cdot l a c Z$
\end{abstract}

\section{Introduction}

The renin-angiotensin system is under the control of a negative feedback regulation that involves the renin-secreting cells of

Address correspondence to Taiji Matsusaka, Division of Nephrology, Department of Pediatrics, Vanderbilt University Medical Center, MCN C4204, Nashville, TN 37232-2584. Phone: 615-322-7931; FAX: 615-322-7929.

Received for publication 6 June 1996 and accepted in revised form 31 July 1996.

J. Clin. Invest.

(C) The American Society for Clinical Investigation, Inc.

0021-9738/96/10/1867/11 \$2.00

Volume 98, Number 8, October 1996, 1867-1877 the juxtaglomerular $(\mathrm{JG})^{1}$ apparatus. Since JG cells are rich in AT1 receptors $(1,2)$, it is assumed that the feedback is driven by a direct angiotensin-AT1 receptor interaction at the level of JG cells. Indeed, it was shown in vitro that angiotensin II (Ang II) suppresses renin release from rat kidney slices (3) and isolated perfused JG apparatus (4). Also, a "subpressor"dose of Ang II infusion partially attenuated the renal renin mRNA stimulated by treatment with enalapril, an Ang I-converting enzyme inhibitor (5). Moreover, a mutant strain of angiotensinogen knock-out mouse is characterized by marked JG apparatus hypertrophy (6). In vivo significance of this short-loop negative feedback mechanism, however, has been difficult to establish as the renin-angiotensin system can be regulated primarily by the baroreceptor and macula densa mechanisms. Indeed, a recent series of studies with administration of exogenous Ang II (7) suggests that the short-loop feedback that is operating in vivo between the local Ang II level and its synthetic activity is positive rather than negative in nature.

Of the two subtypes of AT1 receptors that rodents have, mouse JG cells carry exclusively angiotensin type 1A (AT1A) receptors (8-10). We designed our present study to produce chimeric mice whose JG apparatuses are made up of two clones of cells, one carrying intact, the other totally lacking AT1A receptors. Successful engineering of such mutant mice would allow us to study, by comparing the responses of the two clones of JG cells, the functional significance of the local angiotensin-AT1 receptor interaction for the feedback regulation. The DNA recombinant technology to produce such a chimera has been available $(11,12)$ and involves simultaneous targeting null mutation of the two Agtrla alleles. It was not known, however, how the cell lineage is achieved for the two clones of cells in forming the JG apparatus when chimeric blastocysts develop into whole animals.

In the chimeric mice successfully produced in our laboratory, we learned that the two clones of cells that develop from chimeric blastocysts do not homogeneously mix in forming mature kidneys, but instead show patchy distribution, thereby producing cloned JG apparatuses. This clonality was identified by a reporter gene incorporated into the mutant cells. Microscopic comparisons of these cloned JG apparatuses did not support the speculation that the local interaction between angiotensin and AT1 receptors on JG cells may have significant

1. Abbreviations used in this paper: Agt, angiotensinogen gene; Ang II, angiotensin II; AT1A, angiotensin II type 1A (receptor); ES, embryonic stem (cell); GFP, green fluorescence protein; Hgr, hygromycin; JG, juxtaglomerular; KO, knock-out; Neo, neomycin; PFA, paraformaldehyde; WTR, wall thickness ratio. 
impact on the feedback regulation of renin synthesis in $\mathrm{JG}$ cells in vivo.

\section{Methods}

Construction of replacement vector. Two replacement-type targeting DNA constructs were designed to introduce a null mutation into the mouse Agtrla gene through homologous recombination. As shown in Fig. $1 A$, in the AT1A-GFP-Neo construct, the Cla I-EcoRI 190-bp fragment in the AT1A coding region was replaced by the green fluorescence protein (GFP) gene and a neomycin (Neo) resistance gene expression cassette (PGK-Neor). In the AT1A-LacZ-Hgr construct, the lac $Z$ gene and a hygromycin $(H g r)$ resistance gene expression cassette (PGK-Hgr ${ }^{\mathrm{r}}$ ) were used. Both the GFP and lacZ genes were fused with the Agtrla gene at the end of the third transmembrane region in frame, so that both GFP and lacZ fusion proteins are expected to be produced under the control of the endogenous Agtr1a promoter and anchored to the cell membrane. The latter arrangement allows to distinguish the lac $Z$ derived from potential endogenous $\beta$-galactosidase activities, which display cytosolic distribution.

Generation of Agtr1a-deficient mice and AT1A regional knockout mice. Using the above replacement constructs, gene targeting was performed in embryonic stem (ES) cells as previously described (6). Thus, $40 \mu \mathrm{g}$ of the linearized AT1A-GFP-Neo targeting vector was transfected by electroporation into $10^{7}$ E14-1 ES cells (kindly
A
Wild type
Agtr1a allele

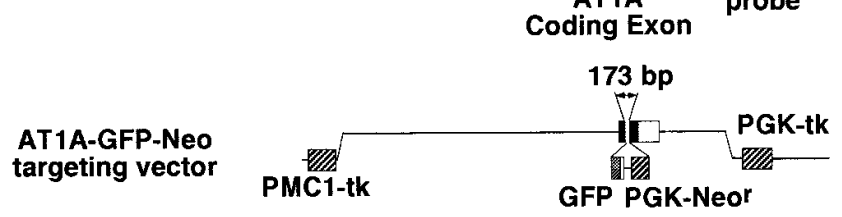

AT1A-LacZ-Hgr targeting vector

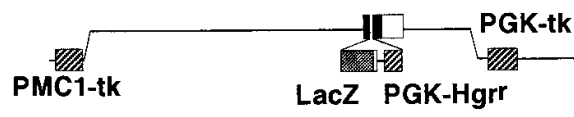

C $\quad+/++/++/-+/--/--/-$

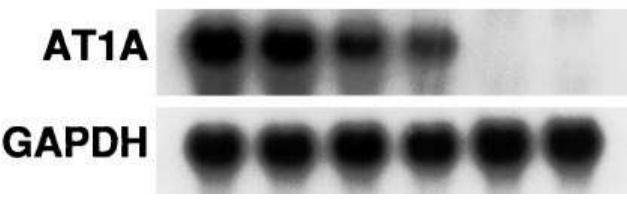

B
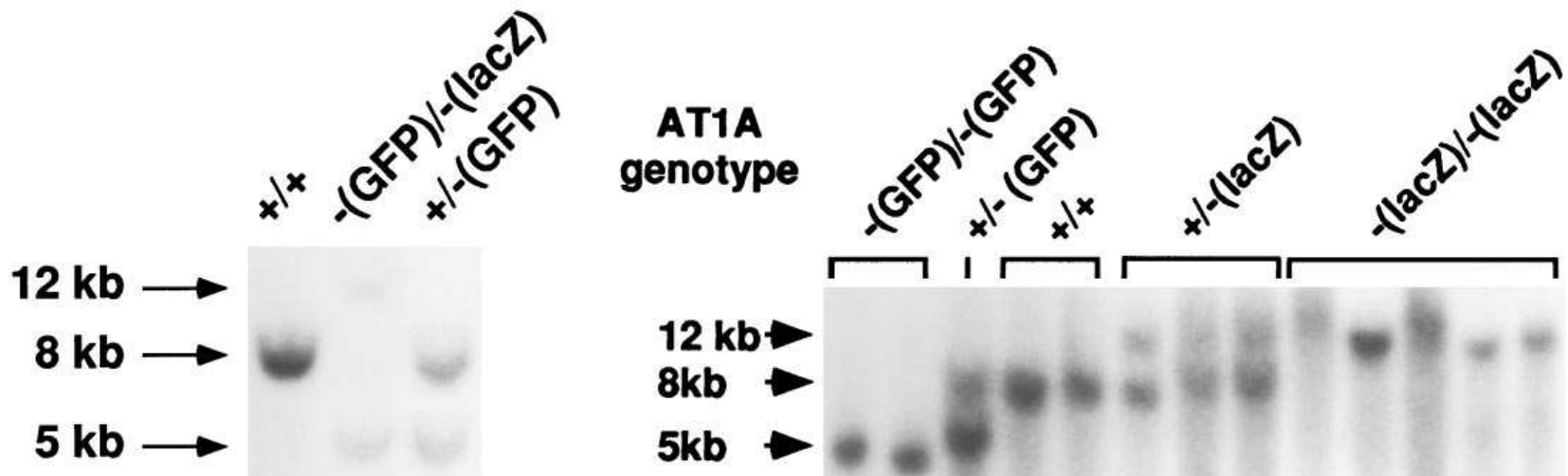

$12 \mathrm{~kb}-$
$8 \mathrm{~kb}-$
$5 \mathrm{~kb}$

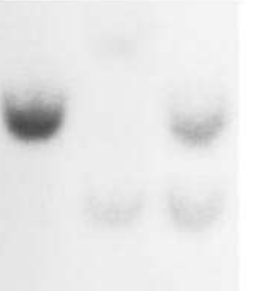

Figure 1. Targeted disruption of the mouse AT1A receptor gene. (A) The structure of the wild-type 129 Sv/J Agtrla gene is shown on top. The AT1A coding region is indicated as a solid box. The targeted alleles shown at the bottom and the second from the bottom result from replacement of the wild-type allele with the targeting vectors, AT1A-LacZ-Hgr and AT1A-GFP-Neo, respectively. The 3' outside probe detects in BamHI-digested genomic DNA an 8-, 5-, or 12-kb fragment unique to the wild-type allele or the allele mutated by AT1A-GFP-Neo or AT1ALacZ-Hgr vector, respectively. ( $B$, left) Southern blot analyses of the targeted ES cell DNA. Correct homologous recombination event is confirmed using a probe $3^{\prime}$ outside the targeting vector. $\left(B\right.$, right) Southern blot analysis of $\mathrm{F}_{2}$ offspring. $15 \mu \mathrm{g}$ DNA from $\mathrm{F}_{2}$ offspring generated by intercrossing heterozygous $\mathrm{F}_{1}$ mice were digested with BamHI, and probed with the $3^{\prime}$ flanking probe. $(C)$ Northern blot analysis for AT1A mRNA. $20 \mu \mathrm{g}$ of each total RNA from the two adult mice $\left(\mathrm{F}_{2}\right.$ generation) were loaded in each lane and probed with a mouse AT1A-specific probe (upper row), and then, after stripping, a glyceraldehyde 3-phosphate dehydrogenase probe (lower row). Ba, BamHI; PMC1-tk and PGK$t k$, negative selection genes. 
provided by Dr. Kitamura, Kyushyu University, Fukuoka, Japan) that had been derived from strain 129/Ola mice. Transfected clones were selected with G418 (0.4 mg/ml; Sigma Chemical Co., St. Louis, MO) and gancyclovir ( $2 \mu \mathrm{M}$; gift from Syntex Inc., Palo Alto, CA). Doubly resistant colonies were picked $\sim 9 \mathrm{~d}$ after transfection and grown individually on 96-well plates. At confluency, the cells in each well were frozen and remaining cells were grown further on 96-well plates for genomic Southern blot analysis. ES cells were grown on irradiated (5,000 rads) primary mouse embryonic fibroblasts, prepared from $\mathrm{Neo}^{\mathrm{r}}$ transgenic mice. Genomic DNA was purified from each doubly resistant ES clone, digested with $B a m H I$, and hybridized with a ${ }^{32} \mathrm{P}$-labeled 0.7-kb BamHI-EcoR I fragment of the Agtr1a genomic DNA, which was external to the $3^{\prime}$ end of the targeting vector (Fig. 1 $A$ ). Homologous recombination was observed in $3 / 288$ doubly resistant ES clones. One targeted clone was injected into C57BL/6 blastocysts. Three chimeras showed germline transmission of the targeted allele when mated to C57BL/6 females.

To disrupt the other allele of the Agtr1a gene at the ES cell level, another targeted ES cell clone was further expanded, electroporated with the AT1A-LacZ-Hgr vector, and selected with hygromycin B $(0.1 \mathrm{mg} / \mathrm{ml})($ Sigma Chemical Co.) and gancyclovir on the layer of irradiated NHL-7 cells (kind gift from Dr. H. Kondo, Osaka University, Osaka, Japan; reference 12). Blastocysts from C57BL/6 mice were injected with the doubly mutated ES cells, and raised into chimeric mice (abbreviated as Agtr1a $-/-\leftrightarrow+/+$ or "AT1A regional knock-out (KO) mice"). One chimeric mouse with high chimerism was chosen for mating with $\mathrm{C} 57 \mathrm{BL} / 6$ females. Through this mating, germline transmission was achieved for both Agtr1a-targeted alleles.

Northern blot analysis for AT1 $m R N A$. RNA was isolated from the kidney using RNAzolB ${ }^{\mathrm{TM}}$ (Tel-Test Inc., Friendswood, TX). 20 $\mu \mathrm{g}$ of RNA were electrophoresed in $1.0 \%$ agarose gel, transferred to a nylon membrane (Hybond $\mathrm{N}+{ }^{\mathrm{TM}}$; Amersham Corp., Life Science Inc., Arlington Heights, IL) and hybridized with a ${ }^{32} \mathrm{P}$-labeled probe specific for the AT1A coding exon. This probe is the HindIII-BglII 0.3-kb fragment in the $3^{\prime}$ untranslated region of the Agtrla gene. The membrane was rehybridized with a human glyceraldehyde 3-phosphate dehydrogenase cDNA probe (Clontech, Palo Alto, CA) as a control for RNA loading.

Mice studied. $\mathrm{F}_{2}$ wild-type (Agtr1a $\left.+/+, n=10\right)$, heterozygous $($ Agtr1a $+/-, n=10)$, and homozygous (Agtr1a $-/-, n=10)$ Agtrla deletion mutants were subjected to various measurements and examinations at 8-16 wk of age. Chimeric regional AT1A knock-out mice (Agtr1a $-/-\leftrightarrow+/+, n=8$ ) were studied at $12-20$ wk of age. Six animals from each of these three groups were subjected to blood pressure measurement as follows: mice were anesthetized with inactin (100 mg/kg body wt, BYK, Konstanz, Germany). PE10 tubing, heated and tapered at one end, was inserted into the left carotid artery. Blood pressure was measured with a transducer (CDXIII; Cobe Laboratories, Inc., Lakewood, CO) that was connected to a MicroMed BP Analyzer (Micro-Med Inc., Louisville, KY).

Tissue from all animals was subjected to microscopic analyses. Detailed morphometric analysis for renal vascular hypertrophy, renin positive areas, and renin mRNA (i.e., in situ hybridization) was done in Agtrla $+/+$ and Agtrla $-/-$ mice ( $n=3$ each). Morphometric analyses for renin positive areas and renin mRNA signal intensity were also done in regional knock-out mice ( $n=5$ and $n=3$ for each analysis, respectively). Three additional Agtr1a -/- mice were placed on low sodium diet $(0.02 \% \mathrm{Na}$; Ralston Purina Co., St. Louis, $\mathrm{MO})$ for $5 \mathrm{wk}$, or high sodium regimen $(\mathrm{NaCl} 1 \%, \mathrm{KCl} 0.2 \%$ in drinking water) plus mineralocorticoid (fludrocortisone acetate $25 \mathrm{mg} / \mathrm{kg}$ i.p., $3 \times$ per week; Sigma Chemical Co.) for $5 \mathrm{wk}$ before killing and morphological assessment.

Histochemical analysis for $\beta$-galactosidase staining. Tissue samples from $\sim 20$ mice of all genotypes were obtained at time of killing for $\beta$-galactosidase staining. $2-\mathrm{mm}$ slices were fixed in $4 \%$ buffered paraformaldehyde (PFA) at $4^{\circ} \mathrm{C}$ for $2 \mathrm{~h}$. Tissues were rinsed (in $0.02 \%$ Nonidet P-40, 0.01\% Na-deoxycholate, PBS) $3 \times$ for $5 \mathrm{~min}$ each, and then stained $\left(2 \mathrm{mM} \mathrm{MgCl}_{2}, 0.02 \%\right.$ Nonidet P- $40,0.01 \% \mathrm{Na}-$ deoxycholate, $20 \mathrm{mM}$ Tris- $\mathrm{HCl}, \mathrm{pH} 7.4,5 \mathrm{mM} \mathrm{K} \mathrm{K}_{3} \mathrm{Fe}[\mathrm{CN}]_{6}, 5 \mathrm{mM}$ $\mathrm{K}_{4} \mathrm{Fe}[\mathrm{CN}]_{6}, 1 \mathrm{mg} / \mathrm{ml}$ Bluo-Gal (GIBCO-BRL, Gaithersburg, MD) in PBS, pH 7.4) at $37^{\circ} \mathrm{C}$ for $48 \mathrm{~h}$. After staining, tissues were rinsed as above and fixed again with $4 \%$ buffered PFA for $5 \mathrm{~h}$ at $4^{\circ} \mathrm{C}$, embedded in paraffin, and 2- $\mu \mathrm{m}$ sections were prepared and used for further conventional or immunohistochemical staining. Alternatively, tissues were fixed in $4 \%$ buffered PFA at $4^{\circ} \mathrm{C}$ for $2 \mathrm{~h}$, placed in $30 \%$ sucrose at $4^{\circ} \mathrm{C}$ for $12 \mathrm{~h}$, embedded in ornithine carbamyl transferase compound, and frozen at $-70^{\circ} \mathrm{C}$. Frozen sections were made in $6-\mu \mathrm{m}$ thickness, fixed in $4 \%$ buffered PFA at $4^{\circ} \mathrm{C}$ for $5 \mathrm{~min}$, rinsed as above $3 \times$ for $5 \mathrm{~min}$ each, and stained in the staining solution at $37^{\circ} \mathrm{C}$ for $48 \mathrm{~h}$. In this staining condition, virtually no endogenous $\beta$-galactosidase was detected in the kidney and the heart.

Morphometrical analysis for renin-producing cells. Kidney sections ( $n=3$ from Agtrla $+/+$ mice; $n=3$ from Agtrla $-/-$ mice) were stained for renin as described previously (6), and all areas with immunoreactive renin were traced with the aid of a camera lucida attachment. The traced areas were scanned with JX-330M scanner (Sharp Co., Osaka, Japan), entered into a Macintosh IIci and calculated using National Institutes of Health Image program.

HindIII-XmnI. 300-bp fragment of rat renin cDNA plasmid (pRen $44 \mathrm{ceb}$ ) was subcloned into pGEM-4 (Promega Corp., Madison, WI) and used as a template to synthesize ${ }^{35} \mathrm{~S}$-labeled antisense and sense cRNA probes. The protocol for in situ hybridization was modified slightly from a previous study (6), using cryosections $(6-\mu \mathrm{m}$ thickness), $2 \mathrm{mg} / \mathrm{ml}$ proteinase $\mathrm{K}$, and a 3-d exposure. All of the in situ hybridization signals for renin mRNA in a given section were scored from 1 to 4: to reflect very faint signal (score 1), distinct signal with each grain separated (score 2), dense signal with grains coalescent (score 3), and very dense signal that completely masked underlying nuclear staining (score 4). After scoring hybridization signals, each renin-producing cell region was identified as wild type (lac $Z$ negative) and mutant (lac $Z$ positive) in adjacent sections stained for $\beta$-galactosidase activity.

Morphometrical analysis for arteries. Multiple nonadjacent kidney sections from wild-type $(n=3)$ or homozygous $(n=3)$ mutant mice were assessed. All cross sections of the interlobular and arcuate arteries identified in these sections were examined morphometrically. Both inner and outer diameters of each artery were measured and the ratio (o.d.-i.d.)/o.d., designated as arterial wall thickness ratio (WTR), was calculated and compared between wild-type and homozygous mutant mice.

In the regional $\mathrm{KO}$ mouse with the highest chimerism, interlobular arteries made up of wild-type and Agtrla null-mutated cells were compared in similar fashion. For this purpose, the genotype of the artery was determined by the lacZ positivity of the JG cells, which were shown by serial section analysis to be anatomically associated with the artery.

Statistical analysis. Data are presented as means \pm SEM. Statistical analysis was performed using the nonparametric Mann-Whitney test for the intensity of renin mRNA in situ hybridization signal, unpaired $t$ test for blood pressure, and both for o.d., wall thickness, WTR of renal arteries, and immunoreactive renin area.

\section{Results}

Production of Agtr1a null-mutant mice. As shown in Fig. $1 \mathrm{~A}$, the AT1A coding exon was disrupted by inserting the GFP or lac $Z$ reporter gene and neomycin or hygromycin resistance gene. A total of $329 \mathrm{~F}_{2}$ offspring were genotyped by Southern blot analysis of tail DNA. Of these, $83(25.2 \%)$ were wild type (Agtr1a $+/+), 170(51.7 \%)$ were heterozygous (Agtr1a $+/-)$, and $76(23.1 \%)$ were homozygous $($ Agtrla $-/-)$ for the targeted null mutation, indicating there was no loss of Agtrla -/animals in utero. Typical Southern blot patterns are shown in Fig. $1 B$. 

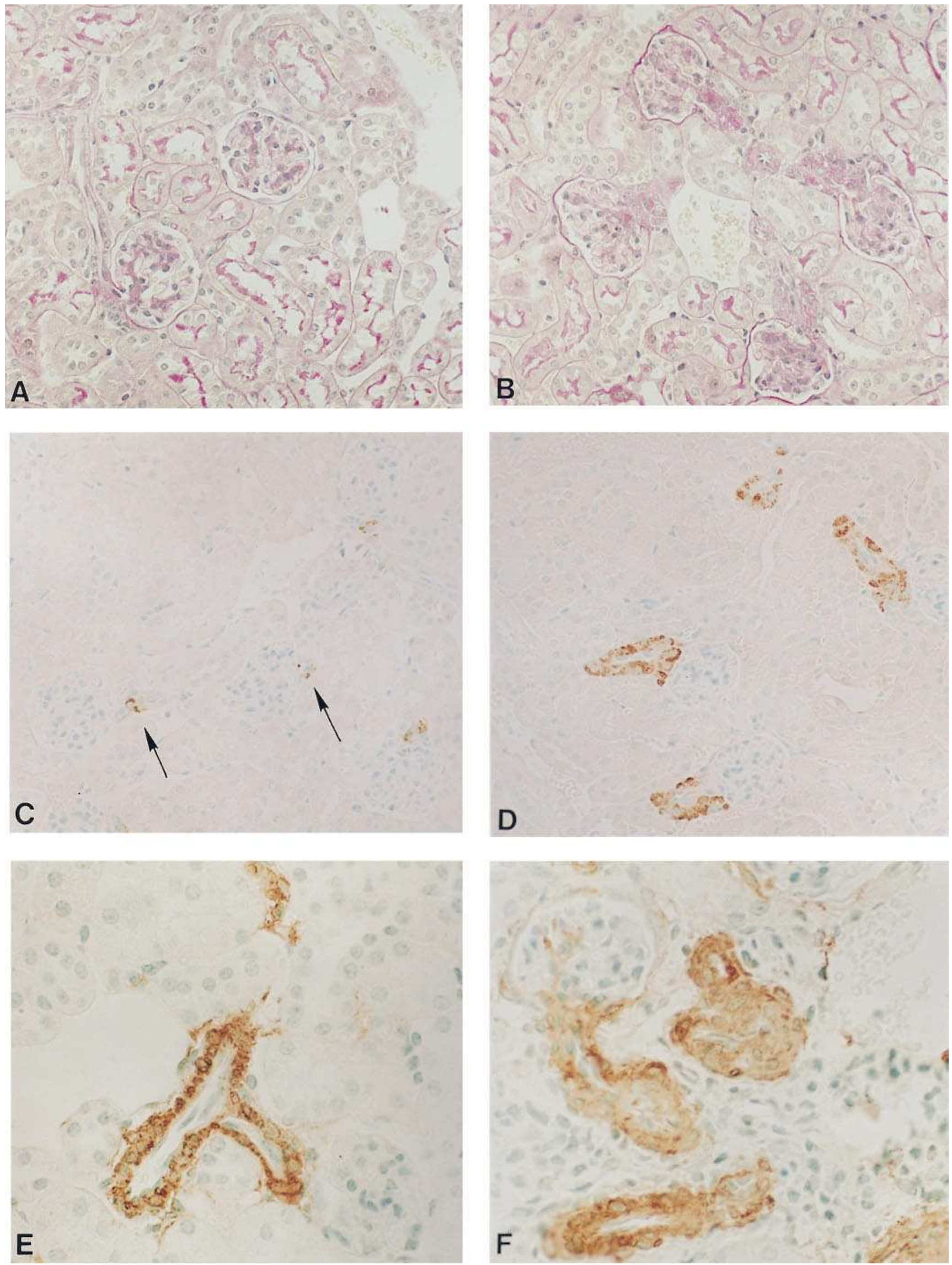
A

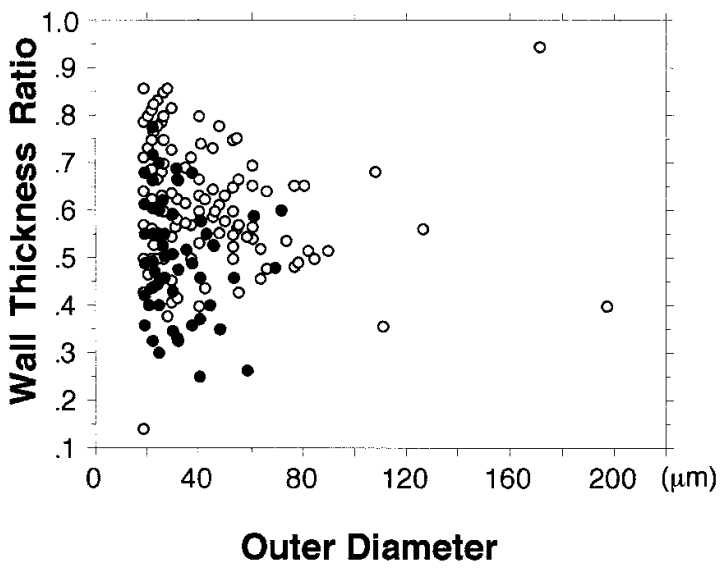

B

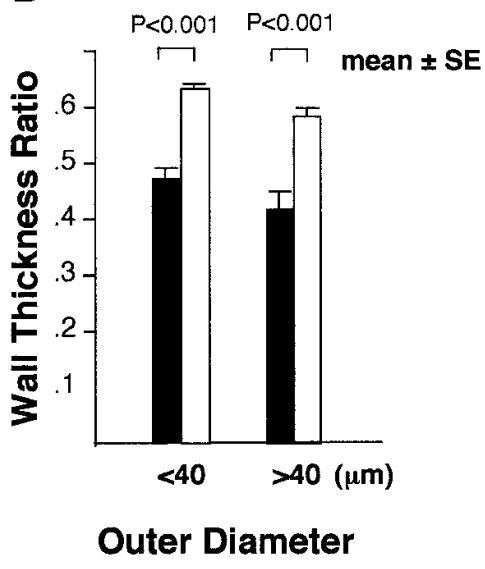

Figure 3. Morphometric analyses of renal arteries in Agtrla $+/+$ and Agtrla -/- mice. (A) Each dot represents a single vessel from Agtrla +/+ (○) or Agtrla -/(○) mice. Arteries from Agtr1a $-/-$ mice have a higher range of outer diameters when compared to Agtrla $+/+$ mice. (B) Values for wall thickness ratio, averaged for small (o.d. $\geq 40 \mu \mathrm{m}$ ) and large (o.d. $<40 \mu \mathrm{m})$, are compared between Agtrla $+/+$ and Agtr1a -/mice. In both of these comparisons, Agtrla -/- mice have significantly greater wall thickness ratio than Agtrla $+/+$ mice. $\mathbf{a}$, Agtrla + /+; $\square$, Agtrla -/-.
To confirm that the mutation had indeed disrupted the Agtrla gene, homozygous mutant animals were assessed. Northern blot analysis of RNA prepared from the kidneys of these animals using an Agtrla-specific 3' probe demonstrated absence of the AT1A 2.3-kb mRNA band in Agtrla -/- mice. In Agtrla +/- mice, the expression of the $2.3-\mathrm{kb}$ AT1A mRNA was decreased to a level approximately half of the Agtrla $+/+$ level (Fig. $1 C$ ).

Phenotypes of Agtr1a-/-mice. All of the phenotypes observed in Agtrla -/- disrupted by the AT1A-GFP-Neo construct $\left[\right.$ Agtrla $\left.a^{g f p} / A g t r 1 a^{g f p}\right]$ and by AT1A-LacZ-Hgr construct $\left[\right.$ Agtrla $\left.{ }^{\text {lacZ }} / A g t r 1 a^{\text {lacZ }}\right]$ are identical except for the reporter gene expression.

Homozygous angiotensinogen null-mutant (Agt-/-) mice are characterized by a significant postnatal growth retardation (6). In contrast, no remarkable growth retardation was observed in Agtrla -/- mice with the mixed genetic background of 129/Ola and C57BL/6.

Arterial blood pressure (systolic/diastolic) measured directly under anesthesia with inactin was, on average, 136/ $102 \pm 6 / 7 \mathrm{mmHg}$ in Agtrla $+/+$ mice, $113 / 83 \pm 2 / 2 \mathrm{mmHg}$ in Agtrla $+/-$ mice $(P<0.01 / P<0.05$, vs Agtrla $+/+)$ and $78 /$ $55 \pm 4 / 6 \mathrm{mmHg}$ in Agtr1a $-/-$ mice $(P<0.001 / P<0.05$, vs Agtrla +/-). These values are comparable to those for Agtrla-targeted mice reported from other laboratories $(9,10)$, although the method used for blood pressure measurement in the present study was different from those studies.

Previous studies have shown that $A g t-/-$ mice have several abnormal renal morphological phenotypes, including delay in glomerular maturation, arterial wall thickening, mesangial expansion, JG cell hypertrophy, interstitial fibrosis, tubular dilatation and hypoplastic papilla. With these in mind, the morphology of the kidney of Agtrla -/- mice was examined microscopically. As shown in Fig. $2 B$, JG apparatuses are markedly enlarged compared to wild type (Fig. $2 A$ ). Immunostaining for renin revealed that the number of renin producing cells is remarkably increased (Fig. 2, $C$ and $D$ ) These patterns are similar to those observed in $A g t-/-$ mice.

The interlobular arteries in Agtrla $-/-$ mice are abnormally hypertrophic (Fig. 2, $E$ and $F$ ), although the afferent arterioles appear normal.

To confirm statistically this phenotype, which is qualitatively apparent, we performed morphometric analysis. As shown in Fig. 3, morphometric examination of renal arteries in Agtrla $-1-$ mice demonstrated larger wall thickness ratio, WTR, (0.622 $\pm 0.080[$ Agtr1a $-/-]$ vs $0.468 \pm 0.013[$ Agtrla $+/+], P<$ 0.001). The difference between Agtrla $+/+$ and Agtrla $-/-$ mice is more manifest when large (o.d. $\geq 40 \mu \mathrm{m}$ ) arteries are compared; the average WTR of the renal arteries with o.d. $\geq$ $40 \mathrm{~mm}$ was $0.410 \pm 0.126$ in Agtrla $+/+$ mice vs $0.587 \pm 0.015$ in the Agtrla $-/-$ mice $(P<0.001)$. Thus, Agtrla knock-out mice have renal arterial lesions similar to those of angiotensinogen knock-out mice, although the lesions are less striking. The arteries in other organs, including the heart, spleen, brain, liver, intestine, and aorta were unremarkable (data not shown).

Other abnormal phenotypes observed in Agt -1- mice (i.e., a delay in glomerular maturation, interstitial fibrosis, tubular dilatation, and hypoplastic papilla) were not observed in Agtrla -/- mice (Fig. 2, data on papilla not shown).

Reporter gene expression in Agtrla $+/-$ and $-/-$ mice. The expression of the reporter gene, lac $Z$, was examined in the kidney of $A g t r 1 a^{\text {lacZ } /+}$ and $A g t r 1 a^{\text {lacZ }} / A g t r 1 a^{\text {lacZ }}$ mice. In both mice, the $\beta$-galactosidase staining was most intensely recognized in JG cells (Fig. 4, $A$ and $B$ ). As predicted from the design of the targeting gene construct, in which the lac $Z$ gene was fused with the Agtrla gene at the end of the third transmembrane region, the plasma membrane was stained exclusively. $\beta$-galactosidase staining was also observed, although less intensely, in the proximal tubule (both apical and basolateral membranes) (Fig. $4 C$ ), and often in the glomerulus (Fig. $4 A$ ). These patterns coincide with those of AT1 mRNA distribution

Figure 2. Kidney specimens from wild-type $(+/+)$ and homozygous Agtrla deletion (-/-) mice. Juxtaglomerular apparatuses of the Agtr1a $-/-$ specimen are markedly enlarged $(B)$, contrasting to the normal appearance of those of $A g t r 1 a+/+(A)$. The number of renin-producing cells is markedly increased in Agtr1a $-/-(D)$ but not in Agtr1a $+/+$ mice (arrows) $(C)$. The interlobular artery of $A g t r 1 a-l-$ mice $(F)$ is abnormally hypertrophic when compared with that of $A g t r 1 a+/+$ mice $(E)$. PAS stain or renin immunostain, $335 \times, A-D ; \alpha$ smooth muscle immunostain, $615 \times, E$ and $F$. 

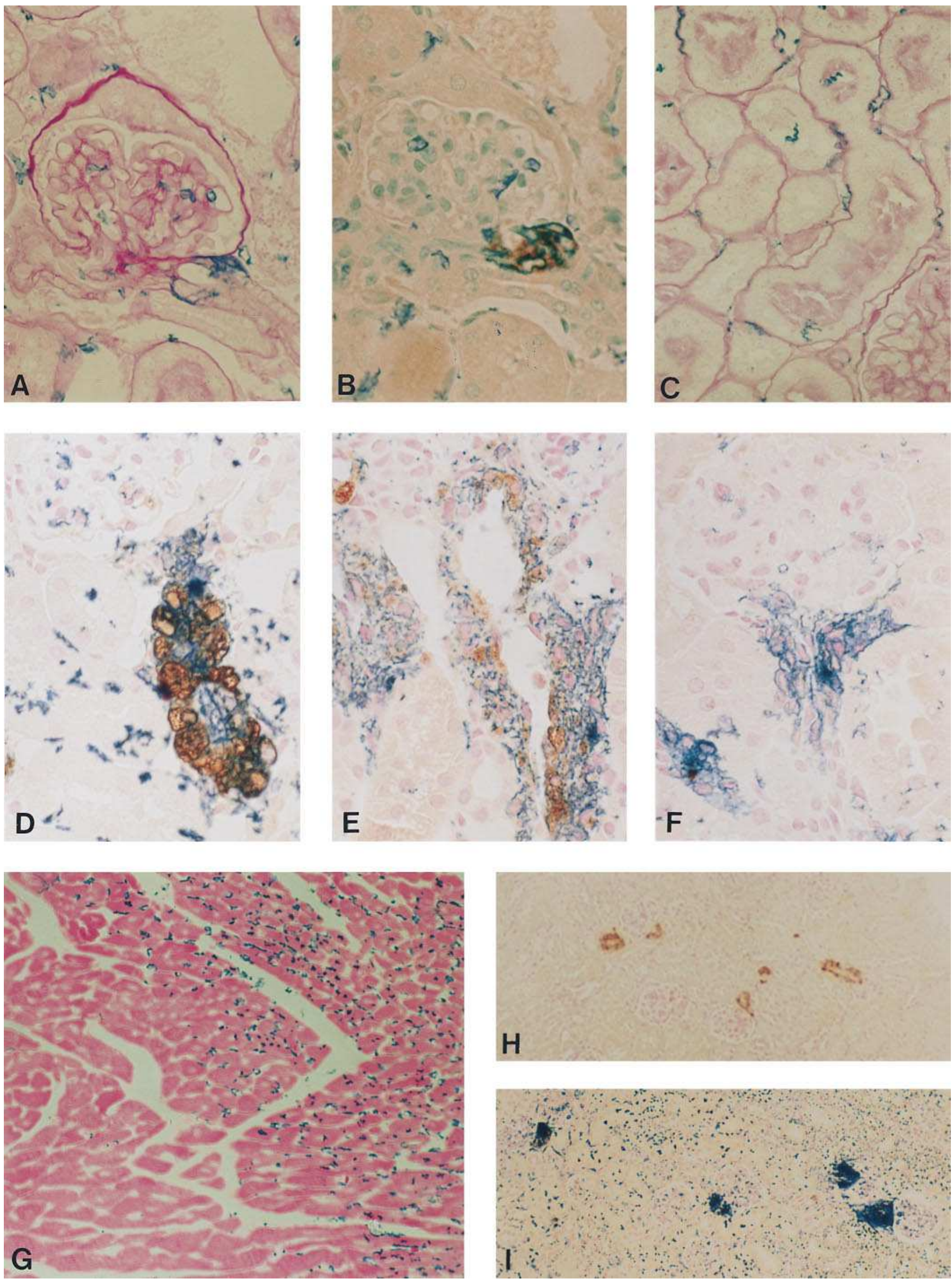
shown by in situ hybridization $(1,2)$, and also those recently reported by Sugaya et al. (10), also using the $l a c Z$ reporter gene in mice. Our further microscopic analysis revealed that both afferent and efferent arteriolar smooth muscle cells adjacent to the glomerular pole, and within the glomerulus, and a few cells that have morphological appearance and location of endothelial and mesangial cells are stained for $\beta$-galactosidase (Fig. $4 A$ ).

The intensity of the $\beta$-galactosidase staining was greater in Agtrla ${ }^{\text {lacZ }} /$ Agtr1 $a^{\text {lacZ }}$ mice than in Agtrla $a^{\text {lacZ } /+~ m i c e ~(F i g . ~} 4$ D). Of interest, the $\beta$-galactosidase intensity was similar in

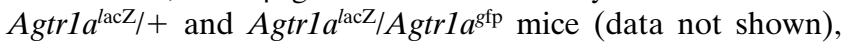
suggesting that the more intense staining in Agtrla $a^{\text {acz/ }}$ Agtrla ${ }^{\text {lacZ }}$ than Agtr1a $a^{\text {lacZ } /}+$ mice directly reflects the twofold greater number of the lac $Z$ gene in the former than the latter, rather than enhanced activity of the Agtrla gene promoter in the former.

The intense signal of $\beta$-galactosidase staining in the JG area is tightly associated with immunoreactive renin positivity (Fig. 4 B). As shown in Fig. $4 D$, in Agtrla -/- mice, reninproducing cells are markedly increased, and in these cells, lacZ is also expressed. To examine whether in these Agtrla -/mice, the renin and lacZ expressions are tightly colocalized in varying physiological conditions, we treated Agtrla -/- mice with a low salt diet or mineralocorticoid plus salt administration. The low salt diet further expanded the renin-producing cells and the same cells also expressed lacZ (Fig. 4 E). Administration of mineralocorticoid and salt nearly completely suppressed the renin expression (Fig. $4 F$ ). The $\beta$-galactosidase staining also became less intense, but remained in the juxtaglomerular area of the afferent arteriole (Fig. $4 F$ ). Thus, the expressions of renin and AT1A are closely associated but do not completely coincide.

The expression of the other reporter gene, GFP, was not discernible in any of the cells, including the JG cells of Agtrla $a^{\text {gfp }} /$ Agtrla $a^{\text {gfp }}$ mice although $g f p$ gene transcripts could be detected by Northern analysis at the whole kidney level (data not shown). It appears that two copies of the gene combined with the degree of Agtrla promoter activity are insufficient to detect the GFP microscopically.

Production of AT1A 'regional KO mice.' To establish an animal model that enables us to study local actions of Ang II, we generated mutant mice, homozygous Agtrla null-mutant wild-type chimeras, or Agtrla $-/-\leftrightarrow+/+$, which are made up of two clones of cells, one with and the other without, the targeted Agtrla genes. Fig. $4 G$ shows a heart section from a re- gional KO mouse stained for $\beta$-galactosidase. The Agtr1a doubly null-mutated cells are recognized as cells carrying lac $Z$ reporter gene activity (blue color), which distribute in a patchy pattern; i.e., in a manner similar to the hair coat color of this chimeric mouse. Similarly, in the kidney, JG apparatuses with or without lacZ expression are observed in a clustered fashion (Fig. 4, $H$ and $I$ ). Thus, we have successfully produced the regional AT1A knock-out mutant mouse model.

Renin expression in regional $\mathrm{KO}$ mice. We next examined whether the abnormal phenotypes observed in Agtrla -/mice (i.e., upregulation of JG renin synthesis and hypertrophic renal interlobular arteries) involves a local action of Ang II on AT1A receptor-bearing cells. In most of the regional $\mathrm{KO}$ mice we studied, the null-mutant JG apparatuses are not enlarged. In one particular regional KO mouse (number 9-1 in Fig. 5), which has the highest chimerism (nearly 100\% of the coat color is agouti and more than $90 \%$ of the JG cell areas and the heart were $l a c Z$ positive), the mutant JG apparatuses are enlarged. Within the same kidney, however, wild-type JG apparatuses are also equally enlarged. We quantified the area of immunoreactive renin for each JG area, which reflects combined size and number of renin-producing cells. As shown in Fig. 5, the areas of immunoreactive renin of regional $\mathrm{KO}$ mice vary from mouse to mouse, but correlate with the degree of their chimerism. Importantly, when the immunoreactive renin areas of wild-type and null-mutant cells are compared for the same mouse, no significant difference was detected. Thus, the immunoreactive renin area in regional $\mathrm{KO}$ mice is determined by the extent of chimerism at the whole animal level, and not by the absence or presence of AT1A receptor at the individual cell level.

To assess renin production, in addition to renin content, more quantitatively within the same tissue specimen, we performed in situ hybridization for renin mRNA using a radiolabeled renin cRNA probe. As shown in Fig. 6, there is no difference in renin mRNA signal between null-mutant and wild-type cells (assessed by $\beta$-galactosidase in adjacent sections) in regional $\mathrm{KO}$ mice. Thus, JG renin production in regional $\mathrm{KO}$ mice is not determined by the absence or presence of AT1A receptor on individual cells.

Renal arteries in regional KO mice. We next examined the renal vascular changes in regional KO mice. Unlike Agtrla $-/-$ mice, there were no abnormally hypertrophic arteries in the kidney from any regional KO mice (data not shown). Even in a regional $\mathrm{KO}$ mouse with extremely high chimerism (mouse 9-1), in which JG apparatuses are enlarged, the inter-

Figure 4. Renal cortex from Agtr1 a $a^{\text {lacZ/ } /+~ m i c e ~ s t a i n e d ~ w i t h ~ B l u o-G a l ~ a n d ~ P A S ~}(A-C)$. $(A)$ Both afferent and efferent arterioles can be identified. $\beta$-galactosidase staining is most intense in the arteriolar portion closest to the glomerulus. $(B)$ An adjacent section from the same kidney stained with Bluo-Gal, methyl green, and antirenin antibody is shown. Of the two arterioles shown in $(A)$ and $(B)$, the one with a larger BluoGal-stained area at the glomerular end carries renin staining, indicating that this is the afferent, and the other efferent arterioles. $(C)$ Another visual field of the renal cortex from an Agtrla $+/-$ mouse stained with Bluo-Gal and PAS is shown. The distribution of $\beta$-galactosidase activity is localized to the cell membrane of proximal tubule cells, both apical and basolateral sides $(615 \times)$. Renin and lacZ expression in an Agtr1 $^{\text {lacZ } /}$ $A g t r 1 a^{\text {lacZ }}$ mouse placed on a normal sodium $\operatorname{diet}(D)$, low sodium diet $(E)$ or high sodium diet + mineralocorticoid $(F)$. The homozygous Agtrla $a^{\text {lacZ }} / A g$ trl $a^{\text {lacZ }}$ mouse characteristically has expanded renin-producing cells in the afferent arteriole $(D)$. The low sodium diet further expanded the renin-producing cells, and the same cells also express lacZ $(E)$. In contrast, renin expression is completely suppressed in a mouse on high sodium diet + mineralocorticoid $(F)$. In the latter, $\beta$-galactosidase staining remains positive in the juxtaglomerular area of the afferent arteriole. Bluo-Gal, renin immunostain, and nuclear fast red staining, $615 \times$. Heart and kidney specimens from homozygous Agtr1a null-mutant wildtype chimeras $(A g t r 1 a-/-\leftrightarrow+/+)(G-I)$. $(G)$, The Agtrla doubly null-mutated Agtr1a $-/-$ cells are recognized as cells carrying lac $Z$ reporter gene activity (blue color), which distribute in a patchy pattern along the cell membrane (Bluo-Gal, $335 \times$ ). Two separate areas of the same kidney in a chimeric mouse show regional absence $(H)$ or presence $(I)$ of $\beta$-galactosidase activity. Bluo-Gal, renin immunostaining, and nuclear fast red stain, $335 \times$. 


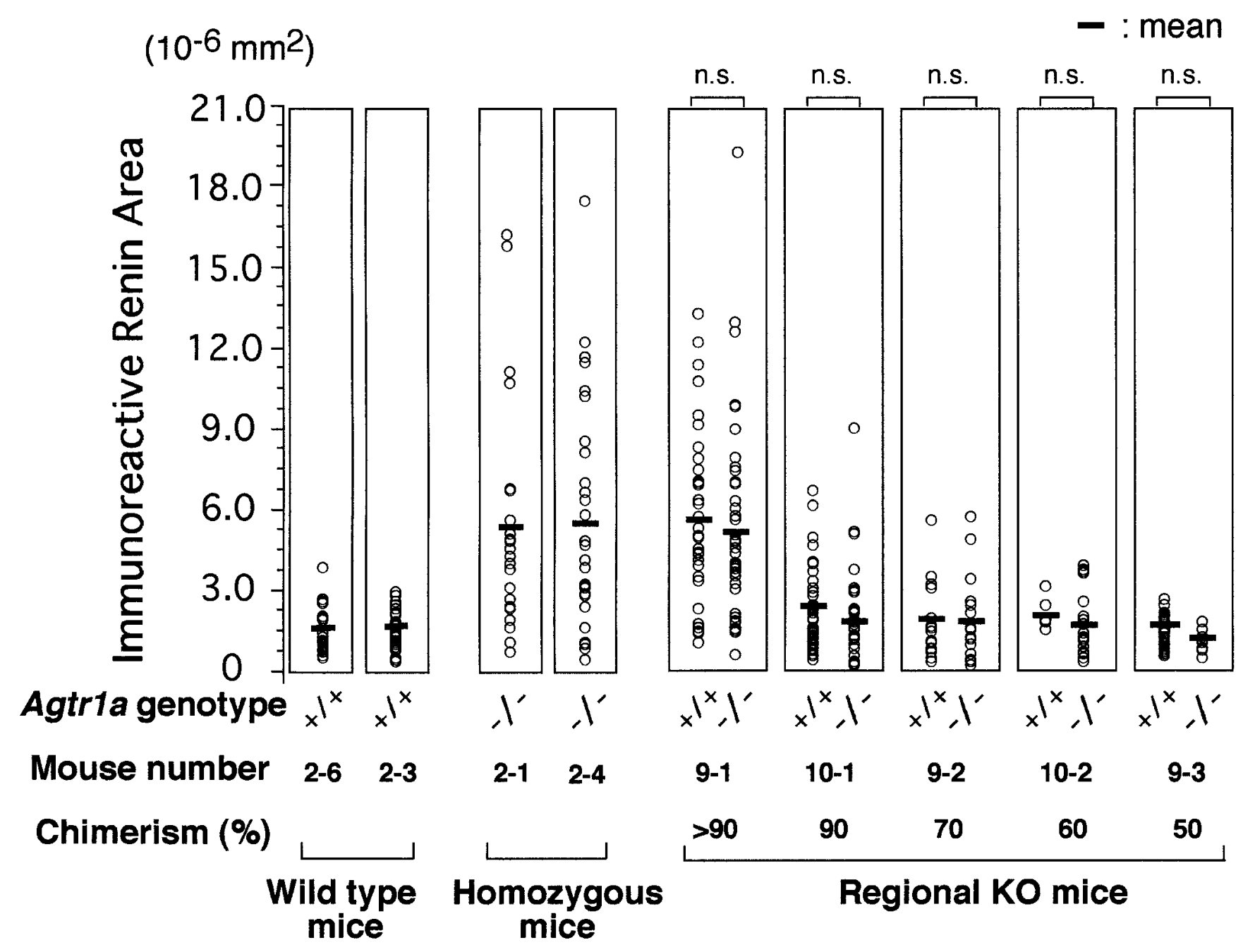

Figure 5. Correlation of immunoreactive renin in kidneys and extent of chimerism in Agtrla $+/+$, Agtrla $-/-$ and Agtrla $-/-\leftrightarrow+/+$ mice. Each rectangle contains data from a single animal. For regional KO mice, Agtr1a $-/-\leftrightarrow+/+$, two columns illustrate the results from two clonally different cells with either Agtrla $+/+$ or Agtrla -/- genotype, determined by lacZ positivity. The extent of chimerism is expressed by the percentage of Agtr1a - / - cells occupying the skin as represented by agouti coat color. Each dot depicts the immunoreactive renin area for each juxtaglomerular apparatus. Each horizontal bar represents the mean value for given clonal cells within a given kidney. The area of immunoreactive renin correlates with the extent of mouse chimerism. However, within a given regional KO mouse, no difference is present between Agtrla $+/+$ and Agtrla $-/-$ cells. $n$.s., not significant, two groups of clonal cells within the kidney.

lobular arteries remain nonhypertrophic. To detect subtle changes in renal arteries, the diameter and wall thickness of interlobular arteries were compared between mutant and wildtype cell regions within the same kidneys by serial sections. As lacZ expression, or Agtrla transcriptional activity, is too low to detect in interlobular arteries in Agtrla +/- or Agtrla -/mice or areas, the genotype of the cells in interlobular arteries cannot be determined directly. We therefore assumed that the interlobular arteries that are anatomically connected to lacZexpressing mutant JG cells are composed of mutant cells, and those linked to lacZ-absent wild-type JG cells are made up of wild-type cells. The quantitative assessment based on this assumption showed no difference in diameter or wall thickness between the arteries of wild-type and null-mutant cells in the regional KO mouse with the highest chimerism (Fig. 7). The observation indicates that vascular lesions observed in Agtrla $-/-$ mice are also caused by mechanism(s) other than local action of Ang II on the arteries.

\section{Discussion}

Incorporation of the reporter gene, lac Z, in the Agtrla targeting replacement construct allowed us detailed microscopic analysis of the Agtrla transcriptional activity in the kidney of Agtrla $+/-$ and Agtrla $-/-$ mice since the transcription of lac $Z$ is, by design, driven by the endogenous Agtrla promoter. The pattern of localization of Agtrla transcriptional activity thus surveyed in these kidneys echoed that of mRNA shown by others in normal mice and rats using in situ hybridization (1, $2)$. The results are also in concert with the distribution pattern described recently by Sugaya et al. (10) using a reporter gene method similar to ours. In our study, the design of lacZ fusion protein (i.e., lac $Z$ gene directly series linked with the third transmembrane domain of the Agtrla gene [with the intact leader sequence, important for trafficking AT1A protein]) permitted morphological analyses in even greater detail. Thus, we could demonstrate the lacZ to be at both apical and baso- 


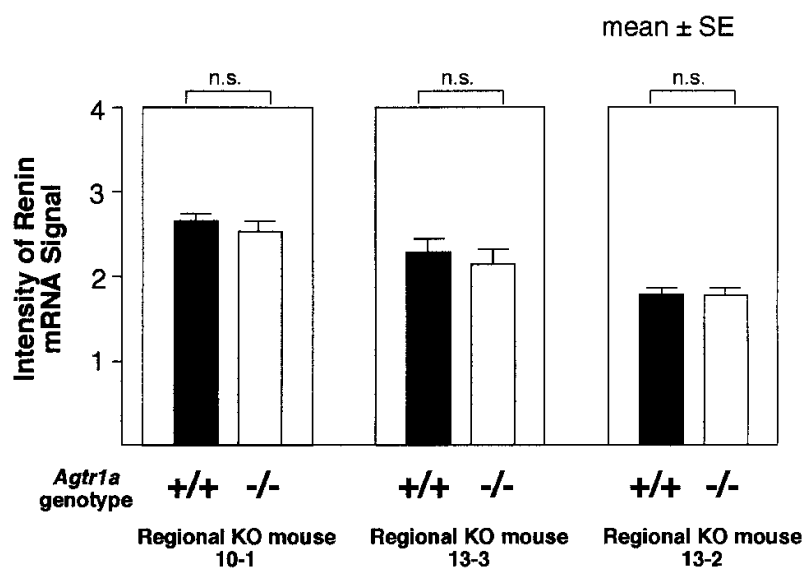

Figure 6. Quantitative analysis of in situ hybridization signals for renin mRNA in regional KO mice. The intensity of signals was determined for each juxtaglomerular apparatus area, and average values were determined for Agtr1a $+/+$ (solid bars) and Agtr1a -/- (blank bars) cells within the same kidney, which were compared in three regional KO mice, Agtr1a $-/-\leftrightarrow+/+$. Renin mRNA signal is not different between Agtrla $+/+$ and Agtrla -/ - cells. n.s., no significant difference.

lateral sides of the proximal tubule cells. LacZ was demonstrated not only in mesangial areas, but also in endothelial cells in the glomerulus. Moreover, lacZ was shown to be localized at the vascular pole end of both afferent and efferent arterioles. Our studies have, therefore, visually demonstrated the localizations of AT1A at sites, some of which have been previously shown only by binding studies (13).

Of interest, the intensity of lacZ staining was essentially identical in $A g t r l a^{\text {lacZ } /+~ a n d ~ A g t r l a ~} a^{\text {lacZ } / A g t r l a ~} a^{g f p}$ mice, in which the copy number of lac $Z$ gene is identically one, yet the copy number of intact Agtrla gene is different (i.e., one vs zero). This observation indicates that no significant feedback regulation exists within the renal AT1A receptor system, where loss of AT1A receptor per se does not lead to transcriptional activation of AT1A via Ang II upregulation or otherwise.

In recent mouse gene targeting studies by us (6) and others (14), deletion mutation of angiotensinogen was shown to result in several abnormal phenotypes in the kidneys, including delay in glomerular maturation, glomerular mesangial expansion, interstitial fibrosis, tubular dilatation, and hypoplastic papilla. The Agtrla -/- mice examined in the present study lack these abnormalities. Several possibilities are entertained to account for the difference. Firstly, inactivation of AT1A may, through stimulating renin-angiotensin release, have activated AT1B, although the latter shows extremely low density in the kidney $(9,10)$. Secondly, the markedly abnormal phenotypes present in angiotensinogen-, but not Agtr1a-deletion mutant mice may reflect important biological actions of non-AT1 Ang receptors. In this regard, AT2 receptor null-mutant mice studied recently $(15,16)$ have no discernible structural abnormalities, thus necessitating prediction of existence of non-AT1 nonAT2 Ang receptor(s), the function of which has heretofore not been characterized. Studies on mutant mice deficient in both Agtrla and Agtrlb genes are warranted to address these important questions.

Apart from these differences from angiotensinogen deletion mutants, Agtrla -/- mice have a few distinctively abnormal phenotypes that are shared with angiotensinogen deletion mutants. Those are low blood pressure, increased renin production, and hypertrophy/hyperplasia of JG cells. Also, interlobular arteries of the kidney were abnormally hypertrophic in Agtr1a -/- mice.

Currently, the notion prevails that the hypertrophy of JG apparatus and renin overproduction seen in several settings (e.g., during angiotensin-converting enzyme inhibitor or AT1 receptor antagonist administration) reflect the existence of a direct negative feedback influence of Ang II to suppress JG renin synthesis through the AT1 receptors abundant on JG cell surface. It appeared that such a negative feedback regulation may underlie the JG hypertrophy and the increased renin production seen in our Agtrla -/- mice. The significance of this
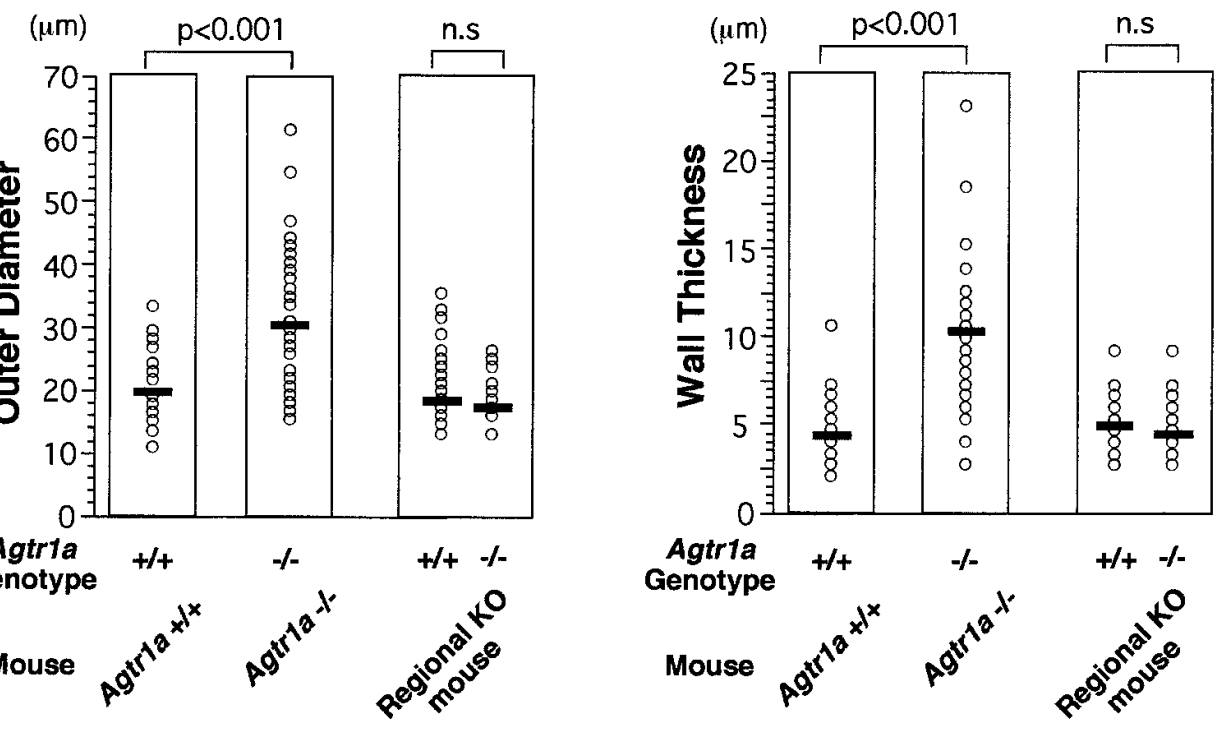

Figure 7. Morphometric analysis of interlobular arteries of Agtrla $+/+$, Agtr1a $-/-$, and Agtr1a $-/-$ $\leftrightarrow+/+$ mouse with a high degree of chimerism. Interlobular arteries are identified by serial sections with the assumption that the interlobular arteries that are anatomically connected to lacZ-expressing mutant JG cells are composed of Agtrla $-/-$ cells, and those linked to lacZ-absent wild-type cells are made up of Agtrla $+/+$ cells. Whereas homozygous Agtrla -1mice are uniformly characterized by thickened arterial walls (see also Figs. 2 and 3), no difference in diameter or wall thickness is present between the arteries of Agtrla $+/+$ and Agtrla $-/-$ cells in a regional $\mathrm{KO}$ mouse with the highest (>90\%) chimerism. Horizontal bars represent mean values. n.s., no significant difference. 


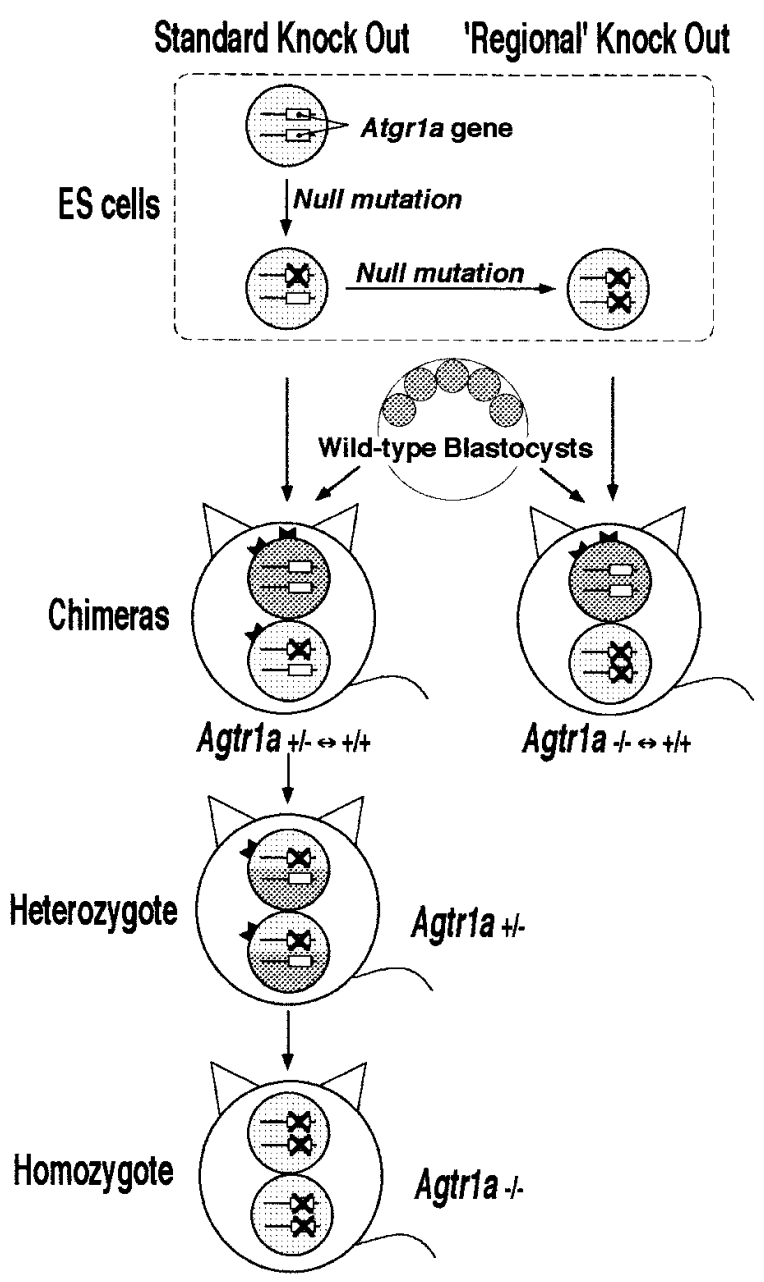

Figure 8. Outline of procedures involved in standard gene knock out (left) and 'regional' gene knock out (right) techniques. Both techniques start with null mutation of one Agtrla allele at the ES cell level in vitro. The standard knock out technique requires only one allele to be targeted on the genome. The ES cells carrying the single targeted allele will then be incorporated into wild-type blastocysts. By mating the resulting chimeras $($ Agtrla $+/-\leftrightarrow+/+)$ with wildtype mice, the targeted allele may be carried by germ cells (i.e., haploid) to produce heterozygotes (Agtrla $+/-$ ). Mating heterozygotes will produce homozygotes (Agtrla-/-). Of note, since in the chimeras produced during the standard knock out procedures at least one Agtrla allele is intact in the somatic cells of both ES cell- and blastocyst-origin, all cells have the potential to express AT1A receptors. In contrast, in the regional knock out technique, both alleles are null mutated at the ES cell level, so that the resulting chimeric mouse (Agtrla $-/-\leftrightarrow+/+)$ is made up of wild-type cells, which can, and homozygous null-mutated cells, which cannot, express AT1A receptors.

direct feedback mechanism has been difficult to test in vivo, however, since other mechanisms, particularly the baroreceptor and the macula densa mechanisms, may also be active in intact animals. This prompted us to engineer the regional AT1A $\mathrm{KO}$ mouse model. Of note, the conventional gene targeting methodology, which involves germline transmission of a nullmutated allele through mutant sperms (i.e., haploid) of chimeric mice to produce heterozygotes, requires only one allele to be targeted on the genome (Fig. 8). Since at least one Agtrla allele is intact in the somatic cells of these chimeric mice, all of those cells have the potential to express AT1A receptors. The regional AT1A KO chimeric mouse model that we engineered is distinctively different in that both Agtrla alleles are null mutated in mutant cells so that this chimeric mouse is made up of wild-type cells, which can, and homozygous null-mutated cells, which cannot, express AT1A receptors (Fig. 8). In engineering this model, we had two unresolved issues. First, since mature kidneys are uniquely abundant in endogenous $\beta$-galactosidase activity, it may be difficult to identify mutant cells if the lac $Z$ is used as a reporter gene by incorporating it into the mutant genome. Second, the information was not available as to how the two clones of cells would be mixed during the maturational process from blastocysts to whole intact animals. It was conceivable that the two clones of cells would become completely homogeneously mixed, thereby making subsequent morphological analysis extremely difficult. The first issue was resolved by designing the lacZ protein to appear on the cell membrane and by using Bluo-Gal as a substrate preferentially used by lacZ. The second issue was resolved as the two clones of cells exhibited patchy distribution in mature organs, including the kidney, heart, and skin coat. Thus, some areas are completely occupied by, and others completely devoid of, Agtr1a null-mutated cells, allowing comparison of the area of wild-type cells to the area of AT1A-deficient cells within the same microscopic field.

By examining lacZ-positive and negative areas of regional $\mathrm{KO}$ mice in great detail, we found that $\mathrm{JG}$ apparatuses are made up of a single clone of cells; i.e., each JG apparatus is made up exclusively of either lacZ-positive or -negative cells. During these examinations, we had a strong impression that the size of JG apparatus is comparable regardless of lacZ positivity in a given chimeric kidney. This initial impression was indeed confirmed by quantitative analysis of renin-positive areas, which showed that the total renin-positive areas are comparable between lacZ-positive and -negative JG apparatuses. Clearly, therefore, within a given kidney, the presence or absence of AT1A receptors on the JG cells does not affect the hypertrophy/hyperplasia of these cells. Moreover, in situ hybridization and immunohistochemical studies showed that both renin mRNA and renin protein are homogeneously distributed throughout a given chimeric kidney. Not surprisingly, therefore, semiquantitative and quantitative analyses of renin mRNA and protein, respectively, demonstrated that, within a given chimeric kidney, these products are present in comparable quantities in JG cells regardless of the presence or absence of AT1A receptors on the cells. Again, therefore, AT1A receptors on the JG cells are not involved in the regulation of renin synthesis in these animals. As JG cells lack AT1B receptors even in Agtrla -/- mice $(9,10)$, it is reasonable to attribute the cause of JG cell hypertrophy/hyperplasia and renin overproduction seen in Agtr1a -/- mice and some chimeras to mechanism(s) that do not involve local action of Ang II. In this regard, the baroreceptor mechanism and the macula densa mechanism, sensing alterations in local pressure and flow, respectively, are strong candidates. ${ }^{2}$ Obviously, studies

2. Most of the regional KO mice including 10-1, 9-2, 10-2, and 9-3 mice in Fig. 5 were normotensive, whereas the blood pressure of the chimeric mouse with JG cell hypertrophy (9-1 in Fig. 5) was low (systolic blood pressure, $96 \mathrm{mmHg}$ in $9-1$ vs $110-120 \mathrm{mmHg}$ in wild-type males by the tail-cuff method). 
are warranted to investigate whether JG cells in vivo are free from local action of Ang II in other conditions as well.

In addition to the JG apparatus, we found in the kidney of Agtrla -/- mice that the renal interlobular artery is abnormally hypertrophied. Similar but more prominent lesions were also observed in the angiotensinogen- and Ang I-converting enzyme null-mutant mice $(6,14,17)$. Of note, this lesion is distinguished from the site of increased renin expression. Thus, whereas renin is present predominantly in afferent arterioles, the lesion is localized in more upstream arteries (i.e., interlobular and arcuate arteries) lacking immunoreactive renin. In contrast with Agtrla -/- mice, chimeric mice with even a high degree of chimerism lack these renal arterial lesions, in both wild-type and null-mutant cell areas. One may speculate, then, that this renal arterial lesion under discussion is also caused by systemic, not local, mechanism(s).

In conclusion, by genetically engineering chimeric mice made up of wild-type- and AT1A-deficient cells, we have provided in vivo evidence against the notion that the feedback regulation of JG renin production by Ang II involves a local Ang II-receptor interaction.

\section{Acknowledgments}

The authors thank Ms. Teresa Bills, Ms. Tracy Moore-Jarrett, Mr. Edward Price, Jr., and Ms. Ellen Donnert for their superb technical assistance, Dr. Tsuyoshi Oikawa for his timely technical advice, and also Dr. Hisato Kondoh for the gift of NHL-7 cells.

This work was supported by National Institutes of Health grants DK-44757 and DK-37868. Dr. T. Matsusaka is the recipient of a fellowship grant from the National Kidney Foundation. Dr. A. Fogo is a recipient of an Established Investigator Award from the American Heart Association.

\section{References}

1. Kakinuma, Y., A. Fogo, T. Inagami, and I. Ichikawa. 1993. Intrarenal localization of angiotensin II type 1 receptor mRNA in the rat. Kidney Int. 43: 1229-1235.

2. Gasc, J.M., S. Shanmugam, M. Sibony, and P. Corvol. 1994. Tissue-spe- cific expression of type 1 angiotensin II receptor subtypes. An in situ hybridization study. Hypertension (Dallas). 24:531-537.

3. Naftilan, A.J., and S. Oparil. 1978. Inhibition of renin release from rat kidney slices by the angiotensins. Am. J. Physiol. 235:62-68.

4. Lorenz, J.N., H. Weihprecht, X. He, O. Skøtt, J.P. Briggs, and J. Schnermann. 1993. Effect of adenosine and angiotensin on macula densa-stimulated renin secretion. Am. J. Physiol. 265:F187-F194.

5. Johns, D.W., M.J. Peach, R.A. Gomez, T. Inagami, and R.M. Carey. 1990. Angiotensin II regulates renin gene expression. Am. J. Physiol. 259:F882F887.

6. Niimura, F., P.A. Labosky, J. Kakuchi, S. Okubo, H. Yoshida, T. Oikawa, T. Ichiki, A.J. Naftilan, A. Fogo, T. Inagami et al. 1995. Gene targeting in mice reveals a requirement for angiotensin in the development and maintenance of kidney morphology and growth factor regulation. J. Clin. Invest. 96:2947-2954.

7. Von Thun, A.M., R.C. Vari, S.S. El-Dahr, and L.G. Navar. 1994. Augmentation of intrarenal angiotensin II levels by chronic angiotensin II infusion. Am. J. Physiol. 266:F120-F128.

8. Burson, J.M., G. Aguilera, K.W. Gross, and C.D. Sigmund. 1994. Differential expression of angiotensin receptor $1 \mathrm{~A}$ and 1B in mouse. Am. J. Physiol. 267:E260-E267

9. Ito, M., M.I. Oliverio, P.J. Mannon, C.F. Best, N. Maeda, O. Smithies, and T.M. Coffman. 1995. Regulation of blood pressure by the type 1A angiotensin II receptor gene. Proc. Natl. Acad. Sci. USA. 92:3521-3525.

10. Sugaya, T., S. Nishimatsu, K. Tanimoto, E. Takimoto, T. Yamagishi, K. Imamura, S. Goto, K. Imaizumi, Y. Hisada, A. Otsuka et al. 1995. Angiotensin II type 1a receptor deficient mice with hypotension and hyperreninemia. $J$. Biol. Chem. 270:18719-18722.

11. Nagy, A., and J. Rossant. 1996. Targeted mutagenesis: analysis of phenotype without germ line transmission. J. Clin. Invest. 97:1360-1365.

12. Sawai, S., A. Shimono, K. Hanaoka, and H. Kondoh. 1991. Embryonic lethality resulting from disruption of both $\mathrm{N}$-myc alleles in mouse zygotes. New Biol. 3:861-869.

13. Bianchi, C., J. Gutkowska, G. Thibault, R. Garcia, J. Genest, and M. Cantin. 1986. Distinct localization of atrial natriuretic factor and angiotensin II binding sites in the glomerulus. Am. J. Physiol. 251:F594-F602.

14. Kim, H.S., J.H. Krege, K.D. Kluckman, J.R. Hagaman, J.B. Hodgin, C.F. Best, J.C. Jennette, T.M. Coffman, N. Maeda, and O. Smithies. 1995. Genetic control of blood pressure and the angiotensinogen locus. Proc. Natl. Acad. Sci. USA. 92:2735-2739.

15. Ichiki, T., P.A. Labosky, C. Shiota, S. Okuyama, Y. Imagawa, A. Fogo, F. Niimura, I. Ichikawa, B.L.M. Hogan, and T. Inagami. 1995. Effect on blood pressure and exploratory behaviour of mice lacking angiotensin II type-2 receptor. Nature (Lond.). 377:748-750.

16. Hein, L., G.S. Barsh, R.E. Pratt, V.J. Dzau, and B.K. Kobilka. 1995. Behavioural and cardiovascular effects of disrupting the angiotensin II type-2 receptor gene in mice. Nature (Lond.). 377:744-747.

17. Krege, J.H., S.W.M. John, L.L. Langenbach, J.B. Hodgin, J.R. Hagaman, E.S. Bachman, J.C. Jennette, D.A. O'Brien, and O. Smithies. 1995. Malefemale differences in fertility and blood pressure in ACE-deficient mice. Nature (Lond.). 375:146-148. 